\title{
Corporate Earnings Management and Financing Policy
}

\author{
Jaisik Gong \\ Professor, Department of Finance and Insurance, Daegu University, Daegu, Korea \\ bkgong@daegu.ac.kr
}

\begin{abstract}
In this study, we conduct an empirical analysis of whether the causal relationship between corporate earnings management and debt policy exists. Jensen (1986) and Harvey (2004) and others argue that firms increase debt levels, or leverage ratios, to reduce agency costs. This study hypothesizes that firms with higher earnings management increase their leverage ratios to reduce agent costs, assuming that the larger the firm's earnings management, the higher the agency costs. This study found that earnings management in Korean firms had a high positive correlation with debt policy, or leverage ratios. This is a result of supporting the agency cost hypothesis that Korean companies with larger earnings management are considered to have higher information asymmetry or agent costs, so that companies with large earnings management are adopting a debt policy that increases leverage ratios to reduce agent costs.
\end{abstract}

Keywords: Earnings management, Debt policy, Agency cost

\section{Introduction}

This study conducts an empirical analysis of how the earnings management activities of corporate managers affect corporate debt policy, or leverage ratios. We perform statistical analysis on whether the leverage ratios of companies with large earnings management are significantly higher.

Corporate capital structure policy making is one of the most important issues in corporate financial management. The trade-off theory of capital structure states that a firm's optimal financial leverage ratio is determined by the trade-off or balance between the benefits and costs of liabilities. First, in terms of debt benefits, companies can increase debt to reduce the agency cost between managers and shareholders. Leuz, Nanda and Wysocki [1] suggests that managers or insiders of a company can make earnings management to pursue their own private interests or to hide their low performance from outside investors. Bharath, T. Sunder, J. Sunder and Shyam [2] states that creditors make loan decisions or set loan interest rates based on the reported profits of companies that may have had earnings management.

In this study, earnings management is used as proxy variable for agent conflict or agent cost between the company manager and external investors. Earnings management in the literature has been used as a measure of the quality of earnings or information quality. For example, Giannetti [3] suggests that corporate opacity disclosure policies are used to maintain private control of insiders, so earnings management can be used as an indicator of the informational quality and usefulness of financial statements.

Article history:

Received (January 8, 2020), Review Result (February 16, 2020), Accepted (April 16, 2020) 
Bhattacharya, Daouk and Welker [4] and Lang, Lins and Maffett [5] used earnings management variables as a measure of the degree of information asymmetry that external investors face to the firm's insiders. Similarly, Francis, LaFond, Olsson and Schipper [6] and $\mathrm{Ng}$ [7] used earnings management as a surrogate variable for the quality of information or the quality of earnings. They argue that discretionary decision-making by corporate managers by earnings management is a means that makes the true economic performance of a company available to insiders.

Earnings management is said to make management's cash flows privately available only to their insiders, leading to greater agency conflict or agency cost between managers and external investors. In this case, Jensen [8] argues that outsiders' judgments about the company's cash flows can be misleading if management deliberately attempts to adjust earnings using a deliberately opaque accounting method. Harvey, Lins and Roper [9] reported that corporate leverage has the effect of reducing agency costs.

Therefore, based on the agency cost theory of free cash flow, this study conducts an empirical investigation on whether financial leverage or corporate debt growth is related to earnings management. In other words, the information asymmetry about the cash flow of a company can be said to be worse as the size of earnings management increases. Therefore, the hypothesis premise that companies with high earnings management increase debt to reduce agent costs can be established. The larger the earnings management, the greater the demand for debt due to the mechanism controlling agency costs.

On the other hand, in terms of the debt cost of the trade-off theory of capital structure, one can consider bankruptcy costs or financial stress. Haw, Hu, Hwang and $\mathrm{Wu}$ [10] argues that firms with high earnings management tend to have higher debt ratios because those companies with large earnings managements help facilitate debt negotiations during financial hardships, while avoiding accounting constraints in debt contracts. Indeed, if an entity's reporting profits are favorably presented due to earnings management, credit ratings are expected to reduce their default risk because the ratings are based on the assumption that the company's financial statements are reasonably and accurately prepared. These credit ratings are easy to increase debt. Thus, we can expect a positive correlation between earnings management and financial leverage ratio.

Therefore, the verification hypothesis of this study is as follows.

$\mathrm{H}$ : Firms with high earnings management are expected to have high financial leverage ratios.

This study is organized as follows. The analytical data and statistical methodology of this study are described in Chapter 2. Chapter 3 empirically analyzes how the debt level, or financial leverage ratio, differs significantly in firms that make earnings management. Chapter 4 summarizes the conclusions and implications of this empirical study.

\section{Research data and test model}

The study period is from 2002 to 2017. The companies that were traded in the Korean securities market during the sample period are selected as sample companies.

This study uses the Jones [11] and Dechow, Sloan and Sweeney [12] models to derive discretionary accruals, the main independent variables of earnings management. The net profit before operating special income collected from the entity's financial statements amounts to the total accruals. Since the total accruals depend on the increase in sales and the amount of equipment, the following regression model is estimated, and the estimated and 
residual values of the regression model estimate are divided into non-discretionary accruals and discretionary accruals.

$$
\frac{T A C C i, t}{T A i, t-1}=\beta 0 i \frac{1}{T A i, t-1}+\beta 1 i \frac{R E V i, t}{T A i, t-1}+\beta 2 i \frac{P P E i, t}{T A i, t-1}+\epsilon i, t
$$

Discretionary accruals derived from the above regression equations represent the breadth of earnings management which managers can manipulate at their discretion when reporting a company's earnings. According to Leuz, Nanda and Wysocki [1] and An, Li and $\mathrm{Yu}$ [13], earnings management can be used as substitutes for agency costs between managers and external investors. When firms have high earnings management, they are considered to be high agency costs. The hypothesis of this study can be set to increase debt to reduce agency costs.

Therefore, the main analysis model of this study is a regression model of how discretionary accruals affect the corporate debt policy. The dependent variable in the regression model uses the debt ratio Debt as a substitute for corporate debt policy. The main independent variable in the regression model is the estimated AAC of discretionary accruals obtained from the above equation. Other control variables in the regression model include the total return on assets ROA, the market value-to-book value ratio MKBK, the logarithmic amount of the total asset value, a firm-scale variable Size, and the standard deviation of cash flows CFDStd as an indicator of risk. Finally, statistical tests are performed on the following regression models.

Debti, $t=\alpha 0 i+\alpha 1 i A A C i, t+\alpha 2 i R O A i, t+\alpha 3 i M K B K i, t+\alpha 4 i S i z e i, t+\alpha 5 i C F D S t d i, t+\gamma i, t$

Therefore, this study conducts an empirical analysis on whether there is a positive correlation between discretionary accruals AAC as a surrogate of earnings management and debt leverage ratios Debt through the statistical verification of the above regression model.

\section{Test results}

This chapter runs OLS regression and panel regression on Korean companies listed on the domestic securities market from 2002 to 2017.

[Table 1] shows the results of OLS analysis on the effect of management's earnings management on corporate debt policy. The agency cost hypothesis of free cash flows suggests that the larger the firm's earnings management, the greater the information asymmetry between managers and investors about cash flows, increasing debt to reduce agency costs. Haw, Hu, Hwang and $\mathrm{Wu}[10]$ also argues that if companies report higher reporting profits, they will be more likely to raise debt because credit rating agencies or the capital markets estimate the firms' default risk to be low. In [Table 1], the coefficient estimates for the debt ratio Debt of the absolute discretionary accrual value AAC, the earnings management variable, is 0.609 and the standard error is 0.112 .

This is a test result of the research hypothesis that companies that are expected to have high agency costs because of their large earnings management choose debt policies that increase leverage ratios to reduce agency costs. In addition, this suggests that companies are actively adjusting earnings to increase capital raising by lowering the default risk assessment of investors in the capital market or raising the credit rating of credit rating agencies.

Among the control variables, the coefficient estimates of the return on assets ROA1 and the market-to-book value ratio MKBK, which are profitability indicators, were -207.61 and 0.509 , which showed a very high negative significance. The coefficient estimate of the firm size variable Size 1 is 0.330 , which is very positive. The larger the firm size, the higher the debt level. 
Table 1. The impacts of earnings management on financing policy: OLS analysis result dependent variable: debt (debt ratio)

\begin{tabular}{|c|c|c|c|c|c|}
\hline Variable & DF & $\begin{array}{c}\text { Coefficient } \\
\text { estimates }\end{array}$ & Standard error & t-Val & Pr> ItI \\
\hline Intercept & 1 & -6.703 & 0.48 & -13.89 & $<.0001$ \\
\hline AAC & 1 & 0.609 & 0.112 & $5.41^{* *}$ & $<.0001$ \\
\hline Size1 & 1 & 0.330 & 0.018 & $17.81^{* *}$ & $<.0001$ \\
\hline ROA1 & 1 & -207.61 & 22.26 & $-9.33^{* *}$ & $<.0001$ \\
\hline MKBK & 1 & -0.509 & 0.022 & $-22.46^{* *}$ & $<.0001$ \\
\hline CFDStd & 1 & $2.89 \mathrm{E}-7$ & $2.99 \mathrm{E}-7$ & 0.97 & 0.333 \\
\hline
\end{tabular}

*Note: Debt is the debt ratio or leverage ratio. AAC is the absolute value of discretionary accruals, a variable for earnings management. Sizel is an enterprise-scale variable that is the logarithm of the total assets of the previous year. ROA1 is the total return on assets of the previous year. MKBK is the book-to-market value ratio of common stocks, and CFDStd is the standard deviation of cash flows.

[Table 2] shows the results of panel model analysis to improve the robustness of statistical analysis in consideration of the time series cross-sectional data of this study. The analysis results in [Table 2] are also very similar to the analysis results in [Table 1]. In the panel analysis of [Table 2], the coefficient estimate of the absolute value of AAC, discretionary accrual variable, which is the main independent variable, is 0.474 and the standard error is 0.11. The highly positive significant estimates of surrogate earnings management variable confirmed that the main hypothesis of this study is empirically supported by the fact that the firms with larger earnings management maintain the debt policy that increases the leverage ratios.

Table 2. The impacts of earnings management on financing policy: panel model analysis dependent variable: debt (debt ratio)

\begin{tabular}{|c|c|c|c|c|c|}
\hline Variable & DF & $\begin{array}{c}\text { Coefficient } \\
\text { estimates }\end{array}$ & Standard error & t-Val & Pr> ItI \\
\hline Intercept & 1 & -5.129 & 0.76 & -6.73 & $<.0001$ \\
\hline AAC & 1 & 0.474 & 0.11 & $4.18^{* *}$ & $<.0001$ \\
\hline Size1 & 1 & 0.273 & 0.028 & $9.45^{* *}$ & $<.0001$ \\
\hline ROA1 & 1 & -152.27 & 21.57 & $-7.06^{* *}$ & $<.0001$ \\
\hline MKBK & 1 & -0.550 & 0.033 & $-16.43^{* *}$ & $<.0001$ \\
\hline CFDStd & 1 & $3.98 \mathrm{E}-7$ & 0 & - & - \\
\hline
\end{tabular}

*Note: Debt is the debt ratio or leverage ratio. AAC is the absolute value of discretionary accruals, a variable for earnings adjustment. Size1 is an enterprise-scale variable that is the logarithm of the total assets of the previous year. ROA1 is the total return on assets of the previous year. MKBK is the book-to-market value ratio of common stocks, and CFDStd is the standard deviation of cash flows.

The estimation results for the control variables such as firm size variable, total asset return ROA1, market to book value ratio MKBK, and standard deviation of cash flow CFDStd in [Table 2] are also very similar to those in [Table 1]. 
As a result, even in the case of the control variables, the analysis results in [Tables 1] and [Table 2] show that the leverage ratio is high for companies that have a large earnings management and low earnings quality or large information asymmetry. A high debt policy was found in firms with large earnings management.

\section{Conclusion}

This study conducted OLS analysis and panel analysis on companies listed on the Korean securities market from 2002 to 2017 in order to investigate how managers' earnings management affects their debt policy through adjustment of leverage ratios.

The hypothesis tested in this study is the agency cost hypothesis, which suggests that companies with large earnings management choose debt policies with higher leverage ratios to reduce agency costs resulting from greater degree of information asymmetry between managers and investors.

The analysis results of this study show that the coefficient estimates of the discretionary accrual value AAC, the earnings management variable as proxy value for agency costs, are very positive in both OLS and Panel test analysis. This is the result of empirically supporting the hypothesis raised in this study that companies that make a lot of earnings management implement debt policy that maintains high leverage ratios.

This result also suggests that, in line with $\mathrm{Haw}, \mathrm{Hu}$, Hwang and $\mathrm{Wu}$ [10], companies may aggressively adjust earnings to increase reporting profits in order to reduce default risk assessments in capital markets as part of the debt policy to facilitate capital raising. Through this analysis of the impact of earnings management on corporate financial policy, Korean policy makers need to consider the positive functional aspects such as enhancing the transparency of Korean financial statements and strengthening the monitoring function of the Korean capital market.

\section{Acknowledgements}

This research was supported by the Daegu University Research Grant, 2019.

\section{References}

[1] C. Leuz, D. Nanda, and P. Wysocki, "Earnings management and investor protection: An international comparison," Journal of Financial Economics, vol.69, pp.505-527, (2003) DOI: 10.1016/S0304405X(03)00121-1

[2] S. Bharath, T. Sunder, J. Sunder, and V. Shyam, “Accounting quality and debt contracting," The Accounting Review, vol.83, pp.1-28, (2008) DOI: 10.2139/ssrn.591342

[3] M. Giannetti, "Do better institutions mitigate agency problems? Evidence from corporate finance choices," Journal of Finance Accountingand Quantitative Analysis, vol.38, pp.185-212, (2003) DOI: $10.2139 /$ ssrn. 203768

[4] U. Bhattacharya, H. Daouk, and M. Welker, "The world price of earnings opacity," The Accounting Review, vol.78, pp.641-678, (2003) DOI: 10.22004/ag.econ.127185

[5] M. Lang, K. Lins, and M. Maffett, "Transparency, liquidity, and valuation; international evidence on when transparency matters most," Journal of Accounting Research, vol.50, pp.729-774, (2012) DOI: 10.1111/j.1475-679X.2012.00442.x

[6] J. Francis, R. LaFond, P. Olsson, and K. Schipper, "The market pricing of accruals quality," Journal of Accounting and Economics, vol.2, pp.295-327, (2005) DOI: 10.1016/j.jacceco.2004.06.003 
[7] J. Ng, "The effect of information quality on liquidity risk," Journal of Accounting and Economics, vol.52, pp.126-143, (2011) DOI: 10.1016/j.jacceco.2011.03.004

[8] M. Jensen, "Agency costs of free cash flow, corporate finance, and takeovers," American Economic Review, vol.76, pp.323-329, (1986) DOI: 10.2139/ssrn.99580

[9] C. Harvey, K. Lins, and A. Roper, "The effect of capital structure when expected agency costs are extreme," Journal of Financial Economics, vol.74, pp.3-30, (2004) DOI: 10.1016/j.jfineco.2003.07.003

[10] J. Haw, B. Hu, L. Hwang, and W. Wu, "Ultimate ownership, income management, and legal and extra-legal institutions," Journal of Accounting Research, vol.42, pp.423-462, (2004) DOI: 10.1111/j.1475679X.2004.00144.x

[11] J. Jones, "Earnings management during import relief investigation," Journal of Accounting Research, vol.29, pp.193-228, (1991) DOI: 10.2307/2491047

[12] P. Dechow, R. Sloan, and A. Sweeney, "Detecting earnings management," Accounting Review, vol.70, pp.193-225, (1995) DOI: 10.5281/zenodo.1095448

[13] Z. An, D. Li, and J. Yu, "Earnings management, capital structure, and the role of institutional environ ments," Journal of Banking \& Finance, vol.68, pp.131-152, (2016) DOI: 10.1016/j.jbankfin.2016.02.007

\section{Authors}

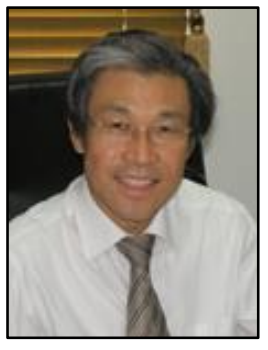

Dr. Jaisik Gong, PhD

Professor, Department of Finance and Insurance, School of Business Administration and Economics, Daegu University, Daegu, Korea 